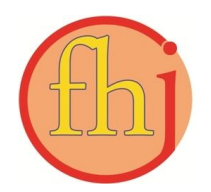

Faletehan Health Journal, 7 (1) (2020) 62-67

www. journal.Ippm-stikesfa.ac.id/ojs/index.php/FHJ

ISSN 2088-673X | e-ISSN 2597-8667

\title{
Implementasi Metode Support Group dalam Meningkatkan Persepsi Pasien Tentang Perawatan Diabetes Mellitus di Kota Bandung
}

\author{
Nandang Jamiat ${ }^{1 *}$, Rahmat $^{1}$ \\ 1Prodi Sarjana Keperawatan STIKes Aisyiyah Bandung, Indonesia \\ *Corresponding Author: ndgjem@yahoo.com
}

\begin{abstract}
Abstrak
Diabetes Mellitus (DM) merupakan penyakit yang tidak dapat disembuhkan, namun dapat dikendalikan. Prevalensi penderita DM di Indonesia 8,5\% dan di Jawa Barat sekitar 29,4\% dari jumlah penduduknya. Sebagai mother of desease, penyakit DM memiliki komplikasi yang serius seperti retinopati diabetik, neuropati, amputasi, penyakit jantung, gagal jantung, stroke dan peripheral arterial disease. Kondisi tersebut menunjukkan perlunya keseriusan dalam penanganan penyakit DM. Diperlukan dukungan dari kader sebagai bagian dari support group bagi peserta Prolanis DM. Tujuan penelitian ini adalah untuk mengetahui implementasi metoda support group dalam meningkatkan persepsi pasien tentang perawatan DM di Kota Bandung. Penelitian ini termasuk jenis penelitian kuantitatif dengan menggunakan rancangan quasi experiment dengan pretest and post test non equivalent control group. Hasil penelitian menunjukkan peningkatan persepsi pasien Prolanis sebesar 3,08 dan peningkatannya dinyatakan sangat bermakna $(p<0,01)$. Edukasi yang dilakukan kader (support group) berpengaruh terhadap peningkatan persepsi pasien DM. Metode support group dengan memberdayakan kader dalam memberikan edukasi sangat bermanfaat dan dapat dijadikan kebijakan di pelayanan kesehatan masyarakat.
\end{abstract}

Kata Kunci: Diabetes M ellitus, Support Group, Prolanis

\section{Implementation of Support Group Methods in Improving Patients Perceptions About Diabetes Mellitus Care in Bandung}

\begin{abstract}
Diabetes M ellitus (DM) is an incurable disease, but it can be controlled. The prevalence of DM sufferers in Indonesia is $8.5 \%$ and in West Java is about $29.4 \%$ of the total population. As a mother of all diseases, DM has serious complications such as diabetic retinopathy, neuropathy, amputation, heart disease, heart failure, stroke, and peripheral arterial disease. These conditions indicate the serious handling of DM is needed. The support from cadres is required as part of the support group for DM Prolanis participants. The purpose of this study was to determine the implementation of the support group methods in improving patients' perceptions of DM care in Bandung. This study used a quantitative method using a quasi-experimental design with a pre-test and post-test non-equivalent control group. The results showed that an increase in the perception of Prolanis patients was as many as 3.08 and the increase was very significant $(p \varangle .01$ ). Education conducted by cadres (support groups) had an effect on improving the perception of DM patients. The support group method by empowering cadres to provide education is very useful and can be used as a policy in public health services.
\end{abstract}

Keywords: Diabetes M ellitus, Prolanis, Support Group. 
Faletehan Health Journal, 7 (1) (2020) 62-67

www. journal.Ippm-stikesfa.ac.id/ojs/index.php/FHJ

ISSN 2088-673X | 2597-8667

\section{Pendahuluan}

Data penderita Diabetes Melitus (DM) kian hari kian bertambah. Menurut hasil Riskesdas tahun 2018, di Indonesia prevalensi penderita DM sebesar 8,5 \% penduduk (Riskesdas, 2018). Prevalensi penderita DM di Jawa Barat sekitar 1,8\% (Riskesdas, 2018) serta angka kejadian Diabetes Mellitus di Kota Bandung sebanyak 4.761 kasus yang terjadi pada tahun 2018 (Dinas Kesehatan Kota Bandung, 2019). Diabetes Melitus memerlukan penanganan cepat dan serius. Hal ini jika diabaikan akan menambah jumlah penderita DM, berisiko bertambah parah, dan menimbulkan munculnya komplikasi yang serius seperti retinopati diabetik, neuropati, amputasi, penyakit jantung, gagal jantung, stroke dan peripheral arterial disease sampai berujung pada kematian. Diabetes Melitus tidak dapat disembuhkan, namun dapat dikendalikan.

Program Pengelolaan Penyakit Kronis (Prolanis) merupakan suatu sistem pelayanan kesehatan dan pendekatan proaktif yang dilaksanakan secara terintegrasi yang melibatkan peserta/penderita DM, Fasilitas Kesehatan Tingkat Pertama (FKTP), dan Badan Penyelenggara Jaminan Sosial (BPJS) Kesehatan yang mengalami penyakit kronis diabetes mellitus dan hipertensi untuk mencapai kualitas hidup yang optimal dengan biaya pelayanan yang efektif dan efisien (BPJS, 2014). Pengelolaan Prolanis dilaksanakan secara terintegrasi oleh tenaga kesehatan di Puskesmas.

Pengelola Prolanis di tiga puskesmas menyatakan adanya penurunan keaktifan peserta Prolanis. Adanya penurunan tingkat keaktifan pasien DM peserta Prolanis di Puskesmas Kujangsari dari 105 menjadi 76 orang, di Puskesmas Talagabodas dari 111 orang menjadi 85 orang. Penurunan keaktifan ini dipengaruhi kurangnya informasi yang diperoleh pasien DM tentang manfaat Prolanis. Hal ini perlu ditindaklanjuti oleh pengelola Prolanis. Salah satu upaya yang dilakukan adalah memberdayakan kader kesehatan. Pelatihan kader sudah dilakukan tahun 2014, namun sampai saat ini belum dilakukan lagi.

Kader kesehatan termasuk kelompok pendukung (support group) yang sangat berperan dalam memberikan edukasi dan motivasi pada pasien DM untuk mampu melakukan perawatan dan kunjungan ke Puskesmas. Pelatihan kader kesehatan khusus tentang DM belum pernah dilaksanakan lagi. Upaya peningkatan pengetahuan kader akan sangat bermanfaat bagi tugas kader kesehatan dan diharapkan dapat memotivasi pasien DM untuk mengikuti program perawatan dengan baik.

Hasil penelitian sebelumnya menunjukkan adanya hubungan antara tingkat kepatuhan pasien DM tipe 2 dengan kadar HbAlc (Syuadzah, Wijayanti, dan Prasetyawati, 2017). Hasil penelitian lain menunjukkan hasil ada hubungan antara aktivitas Prolanis dengan status kesehatan penderita diabetes mellitus dan ada hubungan antara senam Prolanis dan status kesehatan pasien DM (Pradyta, Masfiah , dan Prasetyawati, 2017). Penelitian eksperimen tentang pelatihan pasien DM menunjukkan adanya penurunan kadar gula darah pada penderita DM lansia setelah diberikan latihan penyusunan menu untuk penderita DM secara berkesinambungan (Badriah, 2012). Berdasarkan uraian diatas diperlukan peran kader kesehatan dalam melakukan edukasi terhadap pasien DM. Tujuan penelitian ini adalah untuk mengetahui pengaruh pelaksanaan edukasi kader kesehatan (support group) terhadap peningkatan persepsi pasien DM tentang perawatan DM.

\section{Metode Penelitian}

Penelitian ini termasuk jenis penelitian kuantitatif dengan menggunakan rancangan quasi experiment (eksperimen semu) dengan pretest and post test non equivalent control group. Skema penelitiannya adalah sebagai berikut :

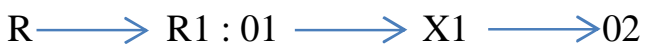

Bagan 1. Alur penelitian

Keterangan :

$\mathrm{R}$ : Responden support group

R1 : Responden pasien DM

01 : Pretest pada kelompok support group dan pasien DM

$\mathrm{X} 1$ : Intervensi penkes support group

02 : Posttest setelah perlakuan pada support group dan pasien DM

Penelitian dilakukan di tiga puskesmas di kota Bandung yaitu : Puskesmas Talagabodas, Puskesmas Pasundan, dan Puskesmas Kujangsari pada bulan Mei sampai Oktober 2019. Populasi pada penelitian ini adalah seluruh kader kesehatan 
dan peserta Prolanis di kota Bandung yang terdapat di seluruh Puskesmas di Kota Bandung. Pemilihan sampel menggunakan metode stratified random sampling yaitu setiap jumlah sampel kader pada tiap puskesmas akan disesuaikan dengan proporsi jumlah peserta terhadap jumlah sampel minimal yang akan diteliti (Notoatmodjo, 2012). Pengambilan sampel berdasarkan pada pertimbangan keaktifan kader, tingkat pendidikan dan kemampuan berkomunikasi. Peneliti dan koordinator Prolanis dari tiga puskesmas peserta Prolanis DM terbanyak, menentukan jumlah kader sebagai responden sebanyak 45 orang, sehingga responden peserta Prolanis sebanyak jumlah responden kader.

Pengumpulan data responden kader (support group) dilakukan saat pelaksanaan refresing kader Prolanis DM di Puskesmas Pasundan. Sedangkan data dari responden peserta Prolanis dilaksanakan pada kegiatan rutin Prolanis di puskesmas masing masing. Alat pengumpulan data berupa angket untuk kader dan angket untuk responden peserta Prolanis DM. Angket berisi tentang pengetahuan konsep DM, dan cara perawatan. Pengambilan data penelitian melalui angket melalui pre test dan post test. Kader dibekali media lembar balik DM untuk edukasi peserta Prolanis DM. Instrumen telah divaliditas (Construksi Validity), dilakukan dengan mengorelasikan skor item instrument dengan rumus Person Product Moment didapat nilai Correlated Item-Total Correlation yaitu sebagai $\mathrm{r}$ hitung. Pengukuran tingkat reliabilitas dilakukan dengan menggunakan sistem komputerisasi dari hasil perhitungan $\mathrm{r}$ pada Cronbach's alfa. Hasil uji validitas dan reliabilitas pada pengetahuan konsep DM dan cara perawatan $(\mathrm{n}=45)$ sebesar 0.712 (reliabel), pengetahuan cara edukasi sebesar 0,734 (reliabel) dan persepsi sebesar 0,747 (reliabel). Dari 28 pertanyaan, yang valid sebanyak 25 pertanyaan. Data tidak terdistribusi normal, maka peneliti menggunakan uji Wilcoxon dan diperoleh p-value $<0.05$ perbedaan bermakna $(\mathrm{p}<0,05)$, perbedaan sangat bermakna $(\mathrm{p}<0,01)$ (Sugiyono, 2017)

\section{Hasil dan Pembahasan}

Profil kader yang terllibat dalam penelitian digambarkan dalam tabel 1. Berdasarkan Tabel 1, diketahui kader yang diteliti berasal dari Puskemas Kujangsari, Pasundan dan Talagabodas dengan sebaran yang merata $(33,3 \%)$, pada umumnya berpendidikan S1 (36\%) dan rata-rata berusia 51,1 tahun dengan rentang usia 30 hingga 67 tahun.

Tabel 1. Profil Kader

\begin{tabular}{lcc}
\hline \multicolumn{1}{c}{ Profil Kader } & F & \% \\
\hline Asal Puskesmas & & \\
$\quad$ Kujangsari & 15 & 33 \\
Pasundan & 15 & 33 \\
$\quad$ Talagabodas & 15 & 33 \\
\hline Pendidikan & & \\
$\quad$ SMP & 6 & 13 \\
SMA & 13 & 29 \\
Diploma & 10 & 22 \\
S1 & 16 & 36 \\
\hline Usia & \multicolumn{2}{c}{} \\
Mean (SD) & $51,1(7,2)$ \\
$\quad$ Median (Min-Max) & $50(30-67)$ \\
\hline
\end{tabular}

Tabel 2. Pengetahuan Kader Sebelum dan Setelah Mendapatkan Pelatihan

\begin{tabular}{|c|c|c|c|c|c|c|}
\hline \multirow{2}{*}{ Variabel } & \multicolumn{2}{|c|}{ Pretest } & \multicolumn{2}{|c|}{ Posttest } & \multicolumn{2}{|c|}{ Perbandingan } \\
\hline & $\%$ & Kategori & $\%$ & Kategori & Selisih & p-value \\
\hline Total Pengetahuan & 77,72 & Baik & 79,50 & Baik & 1,78 & 0,277 \\
\hline $\begin{array}{l}\text { a. Pengetahuan Konsep } \\
\text { DM dan Cara Perawatan }\end{array}$ & 76,98 & Baik & 77,33 & Baik & 0,36 & 0,802 \\
\hline Konsep DM & 76,67 & Baik & 69,56 & Cukup & $-7,11$ & $0,003 * *$ \\
\hline Pola Makan & 86,67 & Baik & 81,78 & Baik & $-4,89$ & 0,119 \\
\hline Olahraga & 70,56 & Cukup & 83,89 & Baik & 13,33 & $0,002 * *$ \\
\hline Farmakologi & 73,70 & Cukup & 82,22 & Baik & 8,52 & $0,021 *$ \\
\hline $\begin{array}{l}\text { b. Pengetahuan Cara } \\
\text { Edukasi }\end{array}$ & 78,96 & Baik & 83,11 & Baik & 4,15 & 0,087 \\
\hline Tehnik Penyuluhan & 75,56 & Baik & 78,67 & Baik & 3,11 & 0,222 \\
\hline Media dan Metoda & 85,78 & Baik & 92,00 & Baik & 6,22 & 0,065 \\
\hline
\end{tabular}

Keterangan : p-value diperoleh dari uji Wilcoxon, karena data tidak berdistribusi normal. *perbedaan bermakna $(\mathrm{p}<0,05), * *$ perbedaan sangat bermakna $(\mathrm{p}<0,01)$ 
Faletehan Health Journal, 7 (1) (2020) 62-67

www. journal.Ippm-stikesfa.ac.id/ojs/index.php/FHJ

ISSN 2088-673X | 2597-8667

Berdasarkan Tabel 2, diketahui pengetahuan kader sebelum pelatihan secara keseluruhan adalah baik $(77,72 \%)$, dan mengalami peningkatan $1,78 \%$ setelah mendapatkan pelatihan menjadi 79,50\% (masih dalam kategori baik), namun peningkatannya dinyatakan tidak bermakna dengan $p$ value $=0,277$ ( $p>0,05)$. Pengetahuan kader terhadap konsep DM dan cara perawatan sebelum pelatihan adalah baik (76,98\%), dan mengalami peningkatan $0,36 \%$ setelah mendapatkan pelatihan menjadi $77,33 \%$ (masih dalam kategori baik), namun peningkatannya dinyatakan tidak bermakna ( $p$ value $=0,802)$.

Pengetahuan kader tentang cara edukasi sebelum pelatihan adalah baik $(78,96 \%)$ dan mengalami peningkatan $4,15 \%$ setelah mendapatkan pelatihan menjadi 83,11\% (masih dalam kategori baik). Namun demikian peningkatannya dinyatakan tidak bermakna ( $p$ value $=0,087$ ). Pengetahuan tentang tehnik penyuluhan mengalami peningkatan $3,11 \%$ (75,56\% menjadi $78,67 \%)$. Pengetahuan tentang media dan metoda mengalami peningkatan $6,22 \%$ (85,78\% menjadi $92 \%)$.

Berdasarkan Tabel 3, diketahui peserta Prolanis yang diteliti mayoritas adalah perempuan (78\%) dan rata-rata berusia 66,2 tahun dengan rentang usia 48 hingga 85 tahun.

Berdasarkan Tabel 4, diketahui bahwa persepsi peserta Prolanis terhadap DM dan cara perawatannya secara keseluruhan sebelum pelatihan adalah positif $(2,78>$ rata-rata 2$)$, setelah mendapatkan pelatihan menjadi 3,08 (masih dalam kategori positif), dan peningkatannya dinyatakan sangat bermakna ( $p$ value $0,000<0,01)$. Terjadi peningkatan persepsi tentang konsep DM setelah mendapatkan pelatihan yakni dari 2,95 (positif) menjadi 3,14 (positif) dan $p$ value $0,031<0,05$ (meningkat secara bermakna)._Terjadi peningkatan persepsi tentang pola makan setelah mendapatkan pelatihan yakni dari 2,67 (positif) menjadi 3,13 (positif) dan $p$ value $0,000<0,01 \quad$ (meningkat secara sangat bermakna). Terjadi peningkatan persepsi tentang olahraga setelah mendapatkan pelatihan yakni dari 2,48 (positif) menjadi 2,89 (positif) dan $p$ value $0,004<0,01 \quad$ (meningkat secara sangat bermakna). Terjadi peningkatan persepsi tentang farmakologi setelah mendapatkan pelatihan yakni dari 3,01 (positif) menjadi 3,17 (positif) namun peningkatannya dinyatakan tidak bermakna ( $p$ value $0,155>0,01)$.

Tabel 3. Profil Peserta Prolanis

\begin{tabular}{lcc}
\hline \multicolumn{1}{c}{ Profil Peserta Prolanis } & F & \% \\
\hline Asal Puskesmas & & \\
$\quad$ Kujangsari & 15 & 33,33 \\
Pasundan & 15 & 33,33 \\
$\quad$ Talagabodas & 15 & 33,33 \\
\hline Jenis Kelamin & & \\
$\quad$ Laki-laki & 10 & 22 \\
$\quad$ Perempuan & 35 & 78 \\
\hline Usia & & \\
$\quad$ Mean (SD) & $66,2(8,6)$ \\
$\quad$ Median (Min-Max) & $65(48-85)$ \\
\hline
\end{tabular}

Tabel 4. Persepsi Peserta Pronalis Sebelum dan Setelah Mendapatkan Edukasi dari Kader

\begin{tabular}{lcccccc}
\hline \multicolumn{1}{c}{ Persepsi } & \multicolumn{2}{c}{ Pretest } & \multicolumn{2}{c}{ Posttest } & \multicolumn{2}{c}{ Perbandingan } \\
& Skor & Kategori & Skor & Kategori & Selisih & p-value \\
\hline Persepsi DM dan cara & & & & & & \\
perawatannya & 2,78 & Positif & 3,08 & Positif & 0,31 & $0,000^{* *}$ \\
$\quad$ Konsep DM & 2,95 & Positif & 3,14 & Positif & 0,19 & $0,031^{*}$ \\
Pola Makan & 2,67 & Positif & 3,13 & Positif & 0,47 & $0,000^{* *}$ \\
Olahraga & 2,48 & Positif & 2,89 & Positif & 0,41 & $0,004^{*}$ \\
Farmakologi & 3,01 & Positif & 3,17 & Positif & 0,16 & 0,155 \\
\hline
\end{tabular}

Keterangan : p-value diperoleh dari uji Wilcoxon, karena data tidak berdistribusi normal. *perbedaan bermakna $(\mathrm{p}<0,05), * *$ perbedaan sangat bermakna $(\mathrm{p}<0,01)$. 
Berdasarkan hasil penelitian diperoleh informasi bahwa pengetahuan kader sebelum mendapatkan pelatihan secara keseluruhan adalah baik $(77,72 \%)$, dan setelah pemberian pelatihan mengalami sedikit peningkatan menjadi $79,50 \%$ namun peningkatannya dinyatakan tidak bermakna/sangat kecil. Pemberian informasi kesehatan dalam merubah perilaku sangatlah penting karena akan membentuk sikap dan perilaku individu atau komunitas untuk menyadari dan memelihara kesehatannya (Notoatmodjo, 2010). Hasil penelitian terhadap pengetahuan dan perilaku kader sejumlah 75 orang menunjukkan bahwa 75 responden memiliki pengetahuan, sikap dan tindakan yang baik (Melatunan et al., 2015)

Hasil edukasi kepada kader menghasilkan peningkatan pengetahuan walaupun belum signifikan. Diperlukan pengelolaan yang baik untuk memberikan edukasi kepada kader meliputi waktu pelaksanaan, penyusunan materi yang mudah dipahami kader, kemampuan pemateri, dan metoda edukasi yang menyenangkan bagi kader.

Kader temasuk ke dalam diabetic educator. Kader sebagai diabetic educator dapat bekerjasama dengan tim lain untuk melakukan perannya dalam melakukan edukasi kepada pasien DM. Proses perubahan perilaku kader (diabetic educator) dan penderita DM memerlukan siklus yang meliputi pengkajian, membuat tujuan, perencanaan, pelaksanaan, evaluasi dan dokumentasi (Burke et al., 2014). Diharapkan kader mampu memberikan edukasi kepada pasien DM untuk mengendalikan kadar gulanya. Kader merupakan bentuk pemberdayaan masyarakat yang sangat penting. Pemberdayaan merupakan pendekatan yang dominan dalam mendukung pasien dengan penyakit kronis, khususnya diabetes tipe 2 kearena dapat membangun kapasitas untuk memperkuat keterampilan, kompetensi dan kemampuan kader, sehingga pasien DM dapat mengelola untuk meningkatkan kualitas hidup mereka (Tol et al., 2015). Diabetic educator adalah fasilitator logis perubahan dan sangat penting memasukkan diabetic educator ke dalam pengaturan praktik yang lebih dan beragam akan berfungsi untuk meningkatkan hasil klinis dan kualitas hidup untuk diabetisi (Burke et al., 2014).

Hasil penelitian terhadap peserta Prolanis diperoleh data bahwa peningkatan persepsi menjadi 3,08 dan peningkatannya dinyatakan sangat bermakna $(\mathrm{p}<0,01)$. Persepsi merupakan suatu proses yang didahului oleh proses penginderaan, yaitu merupakan proses diterimanya stimulus oleh individu melalui alat indera. Usaha untuk menyadari atau mengadakan persepsi diperlukan adanya perhatian, yaitu pemusatan atau konsentrasi dari seluruh aktivitas individu yang ditujukan kepada sesuatu atau sekumpulan objek. Penggunaan media lembar balik merupakan upaya untuk menstimulus peserta DM dalam proses edukasi. Media lembar balik merupakan bagian dari faktor pemungkin, dari proses belajar. Proses belajar merupakan upaya yang dilakukan individu untuk merubah pengetahuan dan perilakunya. Terdapat dua hal yang mendukung proses belajar yaitu latihan dan memperoleh tingkah laku atau pengetahuan baru (Notoatmodjo, 2010). Peserta Prolanis meningkat pengetahuannya dapat disebabkan karena informasi yang bersifat langsung dan individual, sehingga peserta fokus mendengarkan dan juga mampu bertanya tentang hal yang kurang jelas setelah dilakukan edukasi.

Dalam meningkatkan pengetahuan harus dilakukan strategi perubahan perilaku yaitu menggunakan kekuatan atau dorongan dan pemberian informasi serta diskusi partisipasi. Kekuatan yang dimaksud adalah upaya keras dari koordinator Prolanis di puskesmas untuk menjalin kerjasama dengan kader sebagai support group dalam meningkatkan edukasi kepada peserta Prolanis DM atau bukan peserta di wilayahnya. Pemberian informasi dari kader (support group) kepada peserta Prolanis merupakan upaya baru yang dapat dilakukan oleh puskesmas dalam meningkatkan kemandirian kesehatan peserta Prolanis khususnya. Kegiatan ini dapat diduplikasikan pada kegiatan lain.

Berdasarkan hasil penelitian Nugraha (2014) diperoleh informasi bahwa pemberdayaan kader dalam memberikan edukasi kepada individu yang lain telah berhasil meningkatkan pengetahuannya (Nugraha., 2014). Pemberian edukasi dari kader kepada peserta Prolanis merupakan bentuk implementasi kegiatan support group di komunitas. Hasil yang diperoleh dari penelitian ini adalah terdapat pengaruh edukasi yang diberikan kader kepada peserta Prolanis. Penelitian melaporkan bahwa adanya penurunan kadar gula darah pada penderita DM lansia setelah diberikan latihan penyusunan menu untuk 
Faletehan Health Journal, 7 (1) (2020) 62-67

www. journal.Ippm-stikesfa.ac.id/ojs/index.php/FHJ

ISSN 2088-673X | 2597-8667

penderita DM secara berkesinambungan (Badriah, 2012). Penelitian tentang kader kesehatan dilaporkan bahwa pembentukan kader diabetes berpengaruh terhadap pengetahuan, sikap dan partisipasi masyarakat dalam pencegahan penyakit DM tipe 2 (Mahardini, 2016).

\section{Simpulan}

Pengetahuan kader sebelum mendapatkan pelatihan secara keseluruhan adalah baik $(77,72 \%)$, dan setelah pemberian pelatihan mengalami sedikit peningkatan menjadi $79,50 \%$ namun peningkatannya dinyatakan tidak bermakna. Persepsi peserta Pronalis sebelum mendapatkan pelatihan secara keseluruhan adalah positif (skor 2,78 > rata-rata 2,00), dan setelah pemberian pelatihan mengalami peningkatan menjadi 3,08 dan peningkatannya dinyatakan sangat bermakna $(\mathrm{p}<0,01)$. Kader kasehatan dapat mempengaruhi pengetahuan dan sikap diabetisi (peserta Prolanis DM).

\section{Referensi}

Badriah, S. (2012). Kelompok Pendukung untuk Pengendalian Faktor Risiko Peningkatan Gula Darah pada Aggregate Lansia Diabetes Melitus di Pasirgunung Selatan Depok.

Http://Lib.Ui.Ac.Id/File?File=digital/203587 91-TA-Siti\%20Badriah.Pdf.

BPJS. (2014). Panduan praktis Prolanis (Program pengelolaan penyakit kronis). Jakarta:BPJS Kesehatan.

Burke, S. D., Sherr, D., \& Lipman, R. D. (2014). Partnering with diabetes educators to improve patient outcomes. Diabetes, Metabolic Syndrome and Obesity: Targets and Therapy, 7, 45.

Dinas kesehatan Kota Bandung. (2019).Laporan Kejadian 2019 Penyakit tidak menular .Bandung: Dinas Kesehatan Kota Bandung

Leonard A. Melatunan, Iyone S.R, Ottar, \& Henry Palandeng (2015) Gambaran Perilaku Kader Kesehatan terhadap Diabetes Melitus tipe 2 di Puskesmas Kota Manado. Jurnal Kedokteran Komunitas dan Tropik : 3 (1).
Mahardini, R. P. (2016). Pengaruh Pembentukan Kader Diabetes Terhadap Partisipasi Wanita Usia Lebih dari 40 tahun dalam pencegahan penyakit DM tipe 2 di Desa Lengkong Kabupaten Banjarnegara. Imu Kesehatan Masyarakat Fakultas Ilmu Keolahragaan Universitas Negeri Semarang.

Melatunan, L. A., Siagian, I., Ottay, R. I., \& Palandeng, H. M. F. (2015). Gambaran Perilaku Kader Kesehatan Terhadap Diabetes Melitus Tipe 2 di Puskesmas Kota Manado. Jurnal Kedokteran Komunitas Dan Tropik, $3(1)$.

Notoatmodjo, S. (2010). Promosi Kesehatan Teori dan Aplikasi, RinekaCipta. Jakarta.

Notoatmodjo, S. (2012). Metodologi penelitian kesehatan (Cetakan VI). Jakarta: Penerbit PT. Rineka Cipta.

Nugraha., N. (2014). Pemberdayaan Kader dengan Pendekatan Intervensi Berjenjang dalam Pelayanan dan Asuhan Keperawatan Komunitas pada Lansia dengan Gangguan Mobilisasi Akibat Rematik di Kelurahan PGS Kota Depok. Faletehan Health Journal, 2(4).

Riskesdas. (2018). Hasil utama RISKESDAS 2018. Online) Http://Www. Depkes. Go. Id/Resources/Download/Info-

Terkini/Materi_rakorpop_2018/Hasil\% 20Riskesdas, 202018.

Sugiyono, T. (2017). Metode Penelitian Kuantitatif, Kualitatif dan R\&D. Alfabeta. Bandung.

Tol, A., Alhani, F., Shojaeazadeh, D., Sharifirad, G., \& Moazam, N. (2015). An empowering approach to promote the quality of life and self-management among type 2 diabetic patients. Journal of Education and Health Promotion, 4. 